Розділ І. Ціннісні орієнтири духовно-інтелектуального виховання, розвиток духовно-інтелектуальних якостей особистості в умовах співпраці й інклюзії

\title{
ВИХОВАННЯ ПОШАНИ ДО УКРАЇНСЬКОЇ КУЛЬТУРИ В ІНОЗЕМНИХ МАЙБУТНІХ ЛІКАРІВ ПІД ЧАС ПРОГУЛЯНКИ САДОМ ШЕВЧЕНКА
}

\author{
Гепенко Л. O. \\ здобувач третього (освітньо-наукового) рівня вищої освіти кафедри \\ освітології та інноваційної педагогіки, Харківський національний \\ педагогічний університет імені Г. С.Сковороди, викладач кафедри \\ української мови, основ психології та педагогіки, Харківський \\ національний медичний університет, м. Харків, Україна
}

Статтю присвячено засобам виховання пошани до культури українського народу в іноземних майбутніх лікарів. Розкрито можливості позааудиторних виховних заходів щзодо взаємодії й порозуміння з іниими народами. Наголошено на незмінності духовних иінностей і необхідності їх збереження та примноження.

Ключові слова. духовно-інтелектуальний розвиток, гуманізація навчально-виховного процесу, національний та загальнолюдський зміст, адаптація.

This article is devoted to the means of educating the respect to Ukrainian culture for foreign future doctors. Possibilities of extracurricular educational activities on interaction and understanding with other nations are revealed. Emphasis is placed on the immutability of spiritual values and the need to preserve and increase them.

Keywords. spiritual and intellectual development, humanization of the educational process, national and universal content, adaptation.

Як відомо, державна політика у сфері освіти в Україні спрямована на реформування освітньої галузі на національних традиціях з урахуванням світових освітніх тенденцій та економічних можливостей держави 3 метою забезпечення всебічного розвитку людини як особистості та найвищої цінності суспільства, розвитку їі таланту, розумових і фізичних здібностей, виховання високих моральних якостей, формування громадян, здатних до свідомого вибору, збагачення та на цій основі інтелектуального, творчого, культурного потенціалу народу, підвищення його освітнього рівня, забезпечення народного господарства кваліфікованими фахівцями.

Метою статті є обгрунтування необхідності знайомити іноземних студентів з українською культурою, що сприяє не лише підвищенню 
духовно-інтелектуального рівня, а й допомагає краще адаптуватися до проживання в чужій для них країні.

В умовах глобалізації світ увійшов у нову реальність, яка вимагає жити за принципами «глобального онлайну», тобто розвиватись в унісон $з$ іншими державами. Наслідком глобалізації $є$ формування й відповідного типу «глобалізованої особистості» — людини, яка швидко інтегрується в «загальне», дещо втрачаючи «особистісне» і «національне». У глобалізованому світі кожній людині й народові потрібно навчитися жити не тільки з урахуванням загальних інтересів, а й зберігати національні корені, ідентичність, традиції [1]. I в той самий час через ознайомлення з культурою українського народу прагнути до духовно-інтелектуального розвитку.

Важливим напрямком діяльності медичних ВНЗ є гуманізація та гуманітаризація навчально-виховного процесу, органічне поєднання в ньому національного та загальнолюдського змісту $[2,83]$.

У нас з'явилася нова можливість нетрадиційно, цікаво й невимушено знайомити іноземних студентів із постатями відомих людей, чиє життя пов'язано з Харковом. Мова йде про нові скульптурні композиції у Саду Шевченка. Як зазначає один з авторів творчого проекту скульптор Олександр Рідний: «Було поставлено завдання, щоб це були не пам'ятники. Щоб це були скульптури без постаментів».

Кожна скульптура має свою назву. Так видатний учений Володимир Вернадський, дитинство якого пройшло в Харкові, з'явився 3 оригінальним рецептом борщу. Скульптура має назву: «Рецепт від академіка Вернадського». Цікавимося у студентів, чи куштували вони справжній український борщ, слухаємо розповіді про їхні національні страви. Розповідаючи студентам про академіка Вернадського, ми наголошуємо на тому, станції метро «Академіка Павлова», «Академіка Барабашова», «Архітектора Бекетова» не є лише назвами, а вшановують пам’ ять видатних людей. Тому, що студенти-іноземці сприймають ці назви як абстрактні поняття. Вони їх часто чують, уміють уживати в контексті. Наприклад: «Я живу біля станції Академіка Павлова». Але абсолютно не замислюються, що це прізвища відомих людей. I під час однієї з екскурсій я бачила щире здивування: «Академік Павлов - це людина?»

У другому циклі ми хотіли б об'єднати постаті Марка Бернеса, Леоніда Бикова — командира «співочої ескадрилії» та Клавдії Шуль- 
Розділ І. Ціннісні орієнтири духовно-інтелектуального виховання, розвиток духовно-інтелектуальних якостей особистості в умовах співпраці й інклюзії

женко й Ісаака Дунаєвського. Творчість цих людей пов'язана 3 подіями Другої світової війни. У кожного народу, на жаль, є свої сумні сторінки. Чомусь людство не робить висновків. Іноземним студентам важко пояснити, що відбувалося у середині минулого століття. Можемо сказати більше, вітчизняні студенти, у сім'ях яких не згадується подвиг дідів, не завжди можуть навіть сказати, хто проти кого воював. А ось через мистецтво, через ту роль, яку виконували митці на фронті, піднімаючи бойовий дух бійців, можна проілюструвати незламність і силу духу нашого народу. Короткі розповіді проілюстровані найбільш відомими творами: Марк Бернес «Журавли», Леонід Биков «Смуглянка», Клавдія Шульженко «Синий платочек», які студенти прослуховують безпосередньо під час екскурсії. Звичайно, іноземні студенти не зрозуміють усіх слів, але, на нашу думку, мистецтво інтернаціональне. I саме це дає змогу долучитися до нього найширшій аудиторії. Говорячи про події Другої світової війни, пояснюємо, чому вулиця називається 23 Серпня, а проспект Перемоги.

Таким чином, прогулянка Садом Шевченка не обмежується лише алеями парку, а має набагато ширшу географію. Уже в аудиторіях пропонуємо студентам переглянути презентації, створені за тематикою екскурсій. Презентації містять зображення самих скульптур, портрети героїв та цікаві факти їхнього життя, а також практичні завдання з дисциплін, які вони вивчають на кафедрі. У подальшому ми плануємо продовжити знайомство з відомими харків'янами.

Отже, провівши екскурсії Садом Шевченка у Харкові для майбутніх іноземних лікарів, можемо стверджувати, що подібні заходи необхідні для подальшого духовно-інтелектуального розвитку представників інтелігенції, вони є цікавими, викликають інтерес до подальшого ознайомлення з історією та культурою українського народу.

\section{Список використаних джерел:}

1. Зарубіжна література (рівень стандарту) : підруч. для 10 кл. закл. загальн. серед. освіти / О.М. Ніколенко, О.В. Орлова, Л. Л. Ковальова. Київ : Грамота, 2018. 208 c. URL : https://zarlit.com/textbook/10klas_4/3.html

2. Лугова Л. О. Роль викладача клінічної кафедри в організації виховної роботи зі студентами медичного вищого навчального закладу. Сучасні підходи до вищої медичної освіти в Україні : матеріали XIV Всеукр. наук.-практ. конф. з міжнар. участю, присвяченої 60-річчю ТДМУ (Тернопіль, 18-19 трав. 2017 р.) : у 2 т. Терноп. держ. мед. ун-т імені I. Я. Горбачевського. Тернопіль : ТДМУ, 2017. Т. 2. С. 83-84. 